\title{
FISSIDENS ARCTICUS BRYHN IN RUSSIA FISSIDENS ARCTICUS BRYHN В РОССИИ
}

\author{
IRINA V. CZERNYADJEVA ${ }^{1}$ \\ ИРИНА В. ЧЕРНЯДЬЕВА ${ }^{1}$
}

Abstract

\begin{abstract}
Fissidens arcticus Bryhn is found in Russia from three localities in Taymir Peninsula and Yamal Peninsula. Its diagnostic characters and the differentiation from $F$. bryoides is discussed. Description and ecological characteristics are provided.

Резюме

Fissidens arcticus Bryhn выявлен в России из трех местонахождений на п-ове Таймыр и п-ове Ямал. Приводятся описание, рисунки, экологическая характеристика вида. Обсуждаются диагностические признаки $F$. arcticus и его отличия от $F$. bryoides.
\end{abstract}

Fissidens arcticus was described in 1906 by Bryhn from the Ellesmere Island, Canadian Arctic Archipelago. Later some specimens of this species were collected in Alaska, Arctic Canada and Greenland. Steere and Brassard (1974) provided the detailed description of $F$. arcticus, list of its localities and the map of its distribution in the North America. In Svalbard F. arcticus has been reported for the first time by Frisvoll (1981).

The taxonomic status of $F$. arcticus remains debatable. Steere (1978) wrote that characters differing $F$. arcticus from $F$. bryoides eventually depend on environmental conditions and that $F$. arcticus may be a form of the extremaly variable $F$. bryoides, growing in unfavorable conditions. Frisvoll (1981) doubted in independence of $F$. arcticus as a separate species too, and suggested to consider its as a variety of $F$. bryoides. Nyholm (1986) accepts $F$. arcticus as a good species and provides its description and illustrations. Frisvoll later changed his opinion and considered F. arcticus as a separate species (Frisvoll, Blom, 1992; Frisvoll, Elvebakk, 1996). F. arcticus is listed in "Red Data Book of European Bryophytes" (1995) as "vulnerable". In the latter publication its distribution is described as including Alaska, Arctic Canada, Greenland and Svalbard. Recently Kannukene \& Matveye- va (1996) reported $F$. arcticus from the Taimyr Peninsula.

In the course of revision of the Yamal collection of the genus Fissidens in LE 2 specimens of $F$. arcticus were found. Thus, 3 localities of $F$. arcticus are known in Russia at present (Fig. 1). These collections confirm the opinion of Steere and Brassard (1974) that F. arcticus has a circumpolar arctic distribution. Description of the specimens from the Yamal Peninsula is provided below.

Fissidens arcticus Bryhn, Rep. 2. Norweg. Arct. Exp. Fram. 2, 1907 Fig. 2

Stems erect, unbranched, 2-6 mm high, rhizoids few, brownish. Leaves 4-10 pairs, erect, lanceolate, acute; nerve ending below or in apex. Upper leaves 1.2-1.5 mm long, 0.3-0.4 mm wide, ratio A/V (apical lamina length/vaginal lamina length) 1:1.3-2.5, dorsal lamina often non reaching stem, border in apical and dorsal laminae consist of one row of cells, partially absent or fragmentary, in vaginal lamina border broad, usually intramarginal, consist of 4-7 rows of cells, often yellowish or brownish. Middle leaves 0.9-1.2 mm long, 0.25-0.35 mm wide, dorsal lamina usually non reaching stem, border in apical and dorsal laminae mostly absent, rarely fragmentary developed. Lower leaves $0.5-0.9 \mathrm{~mm}$ long, 0.2-0.3 mm wide, vaginal lamina weak, always non reaching stem, border in apical and

1 - V.L. Komarov Botanical Institute of the Russian Academy of Sciences, 2 Prof. Popov str., St. Petersburg 197376 Russia - Ботанический институт им. В. Л. Комарова РАН, проф. Попова, 2, Санкт-Петербург 197376 Россия. 


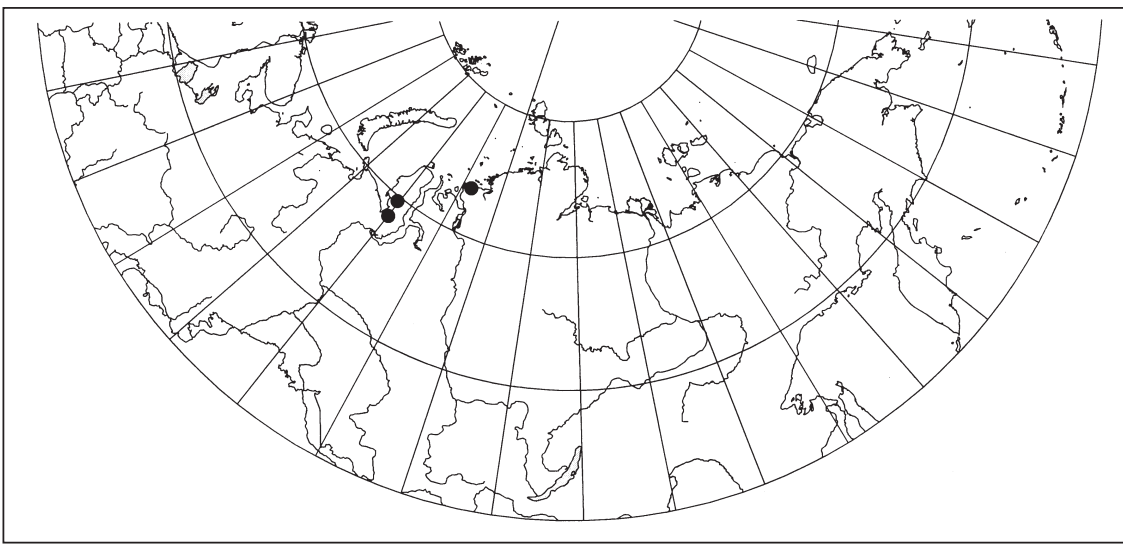

Fig. 1. Distribution of Fissidens arcticus Bryhn in Russia.

dorsal laminae absent, in vaginal lamina very broad, occupies to $30-50 \%$ width of leaf base. Leaf cells pellucid, smooth, irregularly quadrate, rectangular to hexagonal, (8)10-14 $\mu \mathrm{m}$ in diameter, thick-walled.

Synoicous. Sporophytes terminal, solitary. Seta stout, 2-3 mm long; capsula erect, symmetric, $0.6-0.7 \mathrm{~mm}$ long; lid conic to shortly rostrate; peristome single, teeth red to orangebrownish, papillose. Spores 16-20 $\mu \mathrm{m}$, finely papillose to smooth.

Specimens examined. West Siberian Arctic, Yamal Peninsula: Lower Erkutayaha River, Tabortato Lake $\left(68^{\circ} 08^{\prime} \mathrm{N}, 69^{\circ} 05^{\prime} \mathrm{E}\right)$, Chernyadjeva \#32, 21.VII.1994 (LE); Middle Sebayakha River (69 $\left.37^{\circ} \mathrm{N}, 69^{\circ} 27^{\prime} \mathrm{E}\right)$, Chernyadjeva \#12, 28.VII.1992 (LE).

Habitat. On bare clay spot on polygonal tundra, separate stems among Bryoerythrophyllum recurvirostre (Hedw.) Chen (Sebayakha River). On bare sandy soil in nival grass association with Lophozia perssonii Buch et S. Arnell (Erkutayaha River). Lophozia perssonii is found for the first time in West Siberian Arctic (determined by A. Potemkin).

Fissidens arcticus is very close to F. bryoides. Inflorescence type, degree of the leaf border and dorsal lamina expression allow to differentiate these species (Tabl. 1). The identified specimens of $F$. arcticus are synoicous, whereas the studied specimens of $F$. bryoides are autoicous, with antheridia in bud-like branches in leaf axils.

The leaf border of $F$. arcticus in apical and dorsal laminae is often lacking or fragmentary developed; it is broad and frequent pigment- ed in vaginal lamina. The border of $F$. bryoides is different: it is strong, disappears some distance below the leaf apex or confluent with the nerve in plants studied from Chukotka, Arctic East Siberia, Polar Urals. The border is weak, often indistinct in apical part of the specimens from the Yamal Peninsula. In general, the border of $F$. arcticus is weaker in apical and dorsal laminae, and stronger developed in vaginal lamina, than $F$. bryoides.

The degree of development of dorsal lamina is the other important character. The dorsal lamina in both specimens of $F$. arcticus as a rule ends somewhat above the leaf base. In the investigated specimens of $F$. bryoides the dorsal lamina of well-developed leaves reaches the base of leaf, though in separate leaves of some specimens dorsal lamina not reaching the stem.

Areolation of upper leaf is an additional character. In F. bryoides they often form diagonal rows from nerve towards border. This character was noted also by Corley (1980). However in $F$. arcticus these rows are not clear.

Nyholm (1986), Steere and Brassard (1974) pointed on specific intramarginal border of $F$. arcticus. However Frisvoll (1981) mentioned that the similar border occur in $F$. bryoides as well. My observation also found intramarginal border in many plants of $F$. bryoides, so this character is not a valid one for the differentiation of $F$. arcticus and $F$. bryoides.

Nyholm (1986) considered, that ratio $\mathrm{A} / \mathrm{V}$ is a key character for differentiation of $F$. arcticus from $F$. bryoides. In plants studied the ratio $\mathrm{A} / \mathrm{V}$ of well-developed leaves is 1:1.1-2.3 


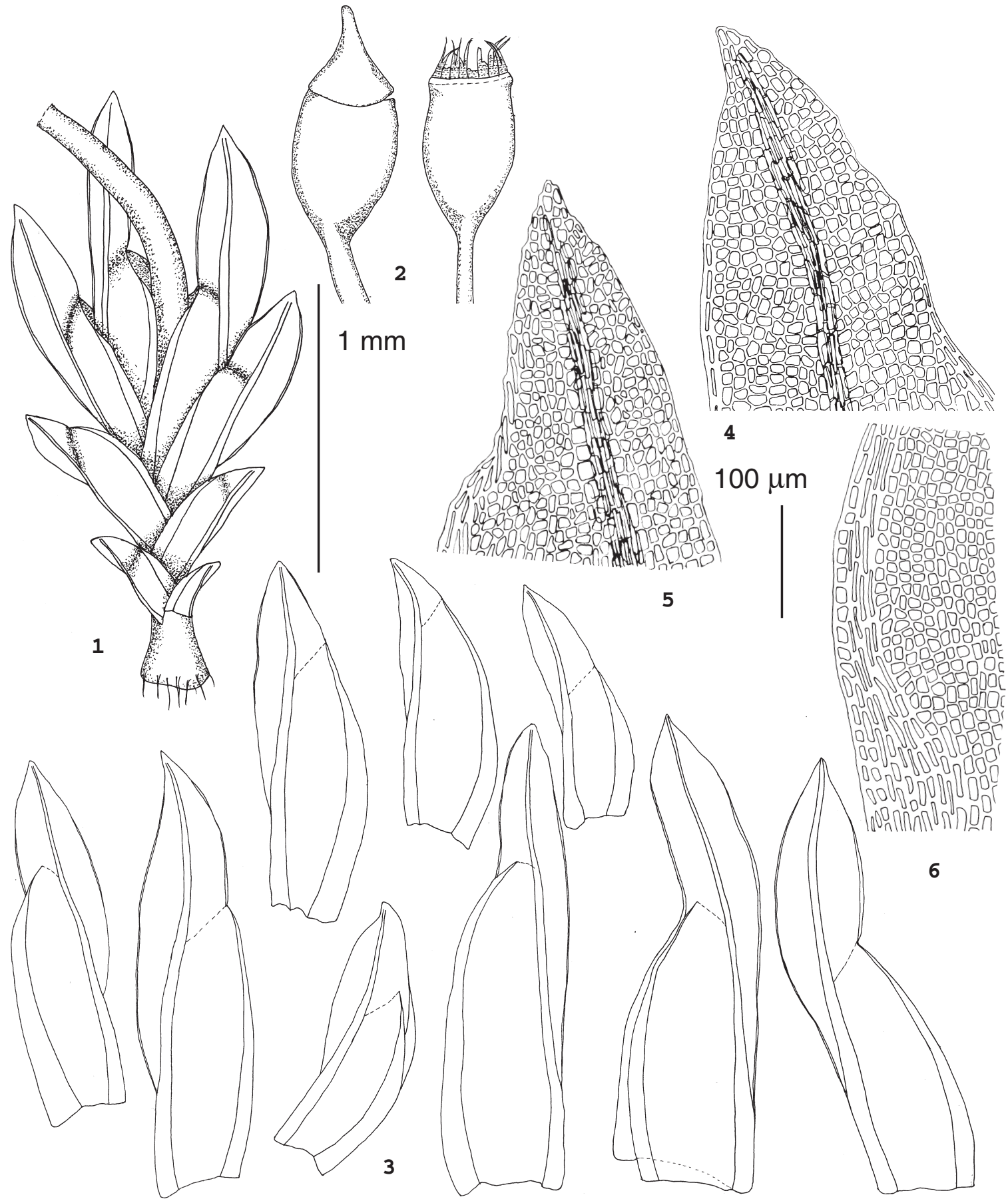

Fig. 2. Fissidens arcticus Bryhn (from Czernyadjeva, \#32): 1 - habitat; 2 - capsules; 3 - leaves; 4-5 - upper laminal cells; 6 - basal leaf cells. Scale bars: $1 \mathrm{~mm}$ for $1-3,100 \mu \mathrm{m}-$ for $4-6$.

Table 1. Comparison of Russian plants of Fissidens arcticus and F. bryoides

\begin{tabular}{llll} 
Species & inflorescence & border in apical and dorsal lamina & type of dorsal lamina \\
$F$. arcticus & synoicous & lacking to fragmentary & $\begin{array}{l}\text { ending above leaf base } \\
\text { reaching leaf base }\end{array}$ \\
\hline F. bryoides & autoicous & strong to fragmentary &
\end{tabular}

$F$. bryoides autoicous strong to fragmentary reaching leaf base 
in $F$. bryoides and $1: 1.3-2.5$ in $F$. arcticus. Thus, this character also is not a helpful one for the differentiation of these taxa.

Thus, different sex distribution, the opposite tendencies of border development and weak development of dorsal lamina persuades me now to keep $F$. arcticus separate from $F$. bryoides. However the degree of taxonomic isolation of
$F$. arcticus requires further investigation.

\section{ACKNOWLEDGEMENTS}

I am very grateful to Dr. A. Potemkin for critical reading of the manuscript, determined by Lophozia perrsonii and for the help with English translation. The work was supported by the Russian Fund of Basic Researches (grants \# 98-04-49828, \# 98-04-49827).

\section{LITERATURE CITED}

BRYHN, N. 1906. Bryophyta in itinere polari Norvagorum secundo collecta. - Rep. 2 Norweg. Arctic Exped. "Fram" 1898-1902. 2: 1-260.

CORLEY, M.F.V. 1980. The Fissidens viridulus camplex in the British Isles and Europe. - J.Bryol. 11(2): 191208.

FRISVOLL, A.A. 1981. Fifteen bryophytes new to Svalbard, including notes on some rare or interesting species. Lindbergia 7(2): 91-102.

FRISVOLL, A.A. \& H.H. BLOM. 1992. Trua moser i Norge med Svalbard; raud liste. - Nina Utredning. 42: 1-55.

FRISVOLL, A.A. \& A. ELVEBAKK. 1996. Part 2. Bryophytes. - In: Elvebakk. A. \& P. Prestrud (eds.) A catalogue of Svalbard plants, fungi algae and cyanobacteria. Norsk
Polarinstitutt Skrifter.: 57-172.

KANNUKENE, L. \& N. MATVEYEVA. 1996. Mosses from the Arctic tundra of the Taimyr Peninsula, Siberia. Proc. Estonian Acad. Biol. 45(1/2): 51-67.

NYHOLM, E. 1986. Illustrated Flora of Nordic Mosses. Fasc. 1. Fissidentaceae-Seligeriaceae. - Lund, Nordic Bryological Sciety.: 1-72.

RED DATA BOOK of European Bryophytes. 1995. - ECCB, Trodheim. 291 p.

STEERE, W. C. 1978. The Mosses of Arctic Alaska. - J. Cramer. FL-9490 Vaduz, 507.

STEERE, W. C. \& G. R. BRASSARD 1974. The systematic position and gegraphical distribution of Fissidens arcticus. - Bryologist 77(2): 195-202. 